\title{
A társadalmi felelősségvállalás és a pénzügyi teljesítmény közötti kapcsolat a magyar bankszektorban a globális válságot követő években*
}

\author{
Deutsch Nikolett - Pintér Éva
}

Az elmúlt évtized hektikus gazdasági változásai és az azt követő szabályozási szigor jelentös és negativ hatással voltak a banki szolgáltatók müködésére. Jövedelmezöségük csökkenését, ügyfeleikkel elveszített bizalmi viszonyukat, valamint versenypozíciójukat olyan eszköztárral próbálták helyreállitani, mely társadalmilag felelös intézményként jelenitette meg a bankokat a pénz- és tökepiacon, létrehozva többek közt a felelös bank, zöld bank, etikus bank fogalmakat. Ám hogy ez a társadalmi felelősség felvállalását elötérbe állitó, hirtelen válaszreakció valójában milyen mértékü, és hogyan hat a bankok teljesitményére hosszú távon, nehezen mérhetö. A cikkben feltérképezzük a pénzügyi szektorra vonatkozó értékelési és mérési módszertanokat, és a magyar bankszektor hét domináns piaci szereplöjének mintáján megvizsgáljuk, milyen kapcsolat van a bankok társadalmi felelösségvállalása, müködésbe integrálása és pénzügyi teljesítménye között a 2006-2013-as idöszakban.

Journal of Economic Literature (JEL) kódok: G00, G20, G21, G30

Kulcsszavak: vállalati társadalmi teljesítmény (CSP), vállalati pénzügyi teljesítmény (CFP), bankszektor, Scholtens-féle CSP

\section{A társadalmi felelősségvállalás motiváló erői a bankszektorban}

A vállalatok társadalmi felelősségvállalásának (angolul corporate social responsibility, röviden CSR) koncepciója és gyakorlati megvalósulása az elmúlt évtizedekben elméleti és gyakorlati szempontból is komoly érdeklődés tárgyává vált. Nem hagyta érintetlenül a gazdaságtudomány különböző tudományterületeit és diszciplínáit sem, gondoljunk csak az elsősorban a stratégiai menedzsmenthez köthető, a szer-

* A jelen kiadványban megjelenő írások a szerzők nézeteit tartalmazzák, ami nem feltétlenül egyezik a Magyar Nemzeti Bank hivatalos álláspontjával.

Deutsch Nikolett adjunktus a Budapesti Corvinus Egyetem Gazdálkodástudományi Karának Vállalkozásfejlesztési Intézetében, a Stratégia és Projektvezetés Tanszéken. E-mail: nikolett.deutsch@uni-corvinus.hu

Pintér Éva adjunktus, okleveles könyvvizsgáló a Pécsi Tudományegyetem Közgazdaságtudományi Karának Pénzügy és Számvitel Intézetében. E-mail: pintereva@ktk.pte.hu

A tanulmány az Emberi Erőforrások Minisztériuma ÚNKP-17-4 kódszámú Új Nemzeti Kiválóság Programjának támogatásával készült.

A magyar nyelvű kézirat első változata 2017. február 6-án érkezett szerkesztőségünkbe.

DOI: http://doi.org/10.25201/HSZ.17.2.124145 
vezeti értékteremtés orientációja körül kialakuló diszkusszióra, az érintetti-elmélet reneszánszára (pl. Rappaport 2006; Porter-Kramer 2011; Ackermann - Eden 2011), vagy a „jó menedzsment elmélet” előtérbe kerülésére (Brammer - Pavelin 2006), továbbá a fenntartható fejlődés vállalati felelősséget hangsúlyozó irányzataira (Deutsch 2011), az üzleti etika vállalati felelősségvállalással és felelősségre vonhatósággal foglalkozó kutatásaira (Joyner - Payne 2002), a társadalmi célú marketingre (Kotler - Lee 2004), az innovációs irodalomban egyre népszerúbbé váló üzletimodell-innovációs kutatásokra (Schaltegger et al. 2012), vagy akár a szervezetek CSR-tevékenységének minősítését és menedzselését szolgáló eszköztár bővülésére. A CSR-tevékenység ösztönzése mellett szóló érvként a szakirodalmi források általában véve a szervezetek reputációjának, imázsának erősödését (pl. Marom 2006), a vevői lojalitás és bizalom emelkedését (Mohr et al. 2001), az üzleti kockázatok és ezáltal a tőkeköltség csökkenését (Bassen et al. 2006), az új termék és/vagy szolgáltatások, illetve piacok irányába történő növekedési lehetőségek kiaknázását (pl. Sen - Bhattacharya 2001), a képzett munkavállalók vonzását és megtartását (Greening - Turban 2000) emelik ki. Míg a CSR-elemzések és a társadalmi teljesítmény (CSP) pénzügyi teljesítményre (CFP) gyakorolt hatásával foglalkozó kutatások középpontjában általában véve a nagyméretű termelő és szolgáltató vállalatok állnak (Orlitzky 2011; Lu et al. 2014), a szektor-specifikus vizsgálatok döntő többsége a banki és pénzügyi szektorra koncentrál. Hazánkban a bankszektort érintően számos nemzetközi összehasonlító tanulmány (pl. Lentner et al. 2015) született a pénzügyi válságot követő szabályozási szigorítást (Borzán et al. 2011), a felügyeleti és könyvvizsgálati felelősség (Lentner et al. 2010) kérdését vizsgálva.

Az elmúlt pár évtizedben ugyanis a bankszektorban a társadalmi felelősségvállalással kapcsolatos jelentések növekedésének (Vigano - Nicolai 2009), a felelős banki termékek biztosításának (Scholtens 2008), a szponzorációs és donációs tevékenységek és CSR-kiadások (Truscott et al. 2009) általánossá válásának, összességében a CSR-gyakorlatok fokozásának lehettünk tanúi. Mindez elsősorban a 2008-as válságra visszavezethető banki múködést érintő szabályozások szigorodására és a pénz- és tőkepiacokkal szembeni bizalmatlanságra adott válaszreakció része, a pénzügyi válság ugyanis ráirányította a figyelmet a bankok múködési és szabályozási hiányosságaira. Ennek következménye az is, hogy a szisztematikus kockázatok kezelésére a Bázeli Bizottság az európai bankok számára a Bázel III. alapelvek és mutatók 2012-2019 közötti szakaszos bevezetését írta elő. Härle et al. (2010) tanulmánya a bázeli tőkekövetelmények integrálásának (a tőkemegfelelési mutató 9 százalékra emelése) következményeként hosszú távon az európai bankok jövedelmezőségében 1,5-4 százalékos csökkenést feltételezett. A bankoknak emellett a válság során szembe kellett nézniük a pénzügyi intézményekkel szembeni bizalmatlansággal is. Meg kellett mutatniuk, hogy a betétesek biztonságát szem előtt tartva felelősséget vállalnak ügyfeleikért, társadalmi szinten is. A bizalmi viszony megszilárdítása és az ügyfelek megtartása érdekében a bankok a szabályozási előírások teljesítésének kiegészíté- 
sére, alátámasztására CSR-jelentéseket adtak ki. Mcllroy (2008) szerint a társadalmi felelősségvállalás egyben meg is óvja a bankokat attól, hogy minden kockázatot beépítsenek a pénzügyi termékekbe, illetve növeli a pénzügyi termékek kockázatainak átláthatóságát. A banki gazdálkodásban, mint más gazdasági társaság esetén is, a cél a jövedelmezőség, a profit biztosítása. Ezt a célt azonban a bankrendszerben sajátos múködési szabályozás mellett (Bázeli standardok, magyarországi 2013. évi CCXXXVII. törvény a hitelintézetekről és pénzügyi vállalkozásokról) három alapvető követelmény - likviditás, szolvencia és prudens múködés - betartása mellett kell elérni. A bankoknak tehát oly módon kell hozamot termelni, hogy közben hosszú távon garantálni tudják ügyfeleik biztonságát, vagyis a tőkének elegendő fedezetet kell nyújtania a potenciális veszteségek fedezésére. Mindemellett pedig rövid távon a múködés biztosításához mindenkor elegendő pénzeszközzel kell rendelkezniük.

A szabályozások szigorodása mellett a banki CSR-tevékenység nagyon jól csengő fogalommá vált, amelynek óriási hatása van a társadalomra (Scholtens 2008). Előtérbe kerülését elsősorban az motiválta, hogy a banki működésre igen nagy hatással van a kockázat és a hírnév, ami erősen függ az ügyfelek megítélésétől és a velük való kapcsolattartástól (McDonald - Lai 2011), hiszen bizalmi viszonyról van szó, amelyet erősíteni kell (Flavian et al. 2005; Pérez et al. 2013). Az érintettekkel való kapcsolatrendszer javítása (Chomvilailuk - Butcher 2013), az észlelhető környezeti láthatóság nemcsak a hírnév javulását hozhatja meg, de a működési költségek és kockázatok csökkentésével versenyelőnyt biztosíthat (Yeung 2011), és potenciális új befektetőket vonzhat, új piacokat teremthet (Tschopp 2012; Tran 2014). Mindezen motivációs tényezők pedig összességükben azt feltételezik, hogy a bankok társadalmi teljesítményének fokozása kedvező hatást gyakorol pénzügyi eredményeikre is.

Cikkünkben a bankok pénzügyi és társadalmi teljesítménye közötti kapcsolatot vizsgáljuk. Ennek feltárásához áttekintjük az ágazatfüggetlen és bankspecifikus szakirodalmi forrásokban a társadalmi (CSP) és pénzügyi teljesítmény (CFP) mérésére, illetve a két teljesítmény kapcsolatának vizsgálatára alkalmazott modelleket és fő következtetéseiket, majd bemutatjuk a 2006-2013-as időszakban a hazai piacon domináns részesedéssel bíró hét, részvénytársasági formában működő bank mintáján végzett regresszióanalízisünk eredményeit.

\section{A társadalmi és pénzügyi teljesítmény kapcsolatának vizsgálata a banki ágazat esetében}

A vállalatok társadalmi felelősségvállalásának és pénzügyi teljesítményének vizsgálatával az elmúlt évtizedekben több empirikus és normatív elemzés is foglalkozott. Ahogyan azonban azt az egyes kutatások eredményeinek összegzéseként megjelenő, metaanalízist folytató tanulmányok (pl. Griffin - Mahon 1997; Orlitzky et al. 2003; Deckop et al. 2006; Beurden - Gössling 2008; Orlitzky 2011; Lu et al. 2014) feltárták, 
a vonatkozó szakirodalmi források nem adnak egyértelmú választ a társadalmi és pénzügyi teljesítmény közötti kapcsolat természetére vonatkozóan, hiszen pozitív, negatív és vegyes kapcsolatra is találhatunk példákat, sőt a kutatások egy része nem is tudott szignifikáns kapcsolatot kimutatni a társadalmi és a pénzügyi teljesítmény között. Ruf et al. (2001), Brammer - Millington (2008), valamint Lee et al. (2009) szerint ezen ellentmondásos eredmények hátterében elméleti és módszertani okok egyaránt meghúzódnak. A szerzők ezen okok közé sorolják a vállalatok társadalmi felelősségvállalásával foglalkozó elméletek hiányosságait, a társadalmi és pénzügyi teljesítményt meghatározó tényezők kiválasztásának eltérő szempontjait és módszereit, a társadalmi teljesítmény szisztematikus, általánosan elfogadott mérési módszereinek hiányát, a CSP-CFP közötti kapcsolattal szemben támasztott, eltérő elméletekre alapozott elvárásokat, valamint a CSP-CFP kapcsolat vizsgálatának módszertani problematikáit.

A legnagyobb nehézséget talán az okozza, ahogyan arra már Griffin (2000) is utal munkájában, hogy mind a CSP, mind a CFP ún. metakonstrukciónak tekinthető, meghatározásuk erős szubjektivitásnak van kitéve, tükrözve az egyes szerzők és az általuk követett elméleti irányzatok - érintetti elmélet, intézményi elmélet, új-intézményi elmélet - eltérő meglátásait. A CSR-t övező élénk figyelem ellenére még ma sem rendelkezünk a CSR általánosan elfogadott definíciójával, az egyes tevékenységek és tartalmi elemek konzisztens tipologizálásával, aminek köszönhetően a vállalatok társadalmi teljesítményének számbavétele is különböző módszerek segítségével történik. A CSP-CFP kapcsolat vizsgálatával foglalkozó tanulmányok elemzése alapján Orlitzky et al. (2003), Deckop et al. (2006), Beurden és Gössling (2008), Orlitzky (2011), valamint Lu és szerzőtársai (2014) is arra a közös megállapításra jutnak, hogy a társadalmi teljesítmény meghatározásának egyik leggyakrabban alkalmazott módszere a vizsgálatba vont szervezetek társadalmi és etikai minősítéseit, reputációs indexeit veszi alapul. A tanulmányok döntő többségében a CSP változót az elemzésbe vont szervezetekre meghatározott Dow Jones Sustainability Index, a FTSE4Good index, az Ethibel Sustainability Index, a KLD ${ }^{1}$, a CRA ${ }^{2}$, a CSRHub ${ }^{3}$, vagy éppen az Asset4esg ${ }^{4}$ indexei alapján kalkulálják. Külön csoportot képeznek azok a vizsgálatok, ahol a CSP meghatározása a vizsgált szervezetek által kiadott éves CSR vagy fenntarthatósági jelentések egyedi elemzése, minősítése alapján történik, ahol a CSP értékére a gazdaságiérték-felosztást, a CSR-költségeket, a környezetvédelmi kiadásokat, vagy a szponzorációs és donációs költségeket alkalmazzák, illetve ahol a társadalmi teljesítmény meghatározása önálló szempontokat tartalmazó kérdőíves felmérés alapján valósul meg. Ezen eltérő érintetti csoportokat, szempontokat és indikátorokat figyelembe vevő módszertanok alkalmazása azonban nemcsak az egyes tanulmányok

${ }^{1}$ KLD Research \& Analytics által kidolgozott CSR-index

${ }^{2}$ A Community Reinvestment Act alapján kialakított CSR-index

${ }^{3}$ ACSRHub.com által kidolgozott CSR minősítési index

${ }^{4}$ Thomson Reuters által kifejlesztett CSR-index 
eredményeinek és következtetéseinek összevetését teszi nehézkessé, hanem annak a veszélyét is magában hordozza, hogy az egyes szervezetek társadalmi teljesítménye is eltérő, akár egymásnak ellentmondó értékeket is felvehet. Hasonló, bár kevésbé bonyolult módon a vállalatok pénzügyi teljesítményének számbavétele is többféle változó segítségével történhet. Egyrészt találkozhatunk a CSR-tevékenységnek köszönhető piaci feltételezések vállalati teljesítményre gyakorolt hatásait is számításba vevő piaci mérőszámok (pl. Tobin- $Q$, részvényárfolyam), a tényleges teljesítményt tükröző számviteli (pl. ROA-, ROE-, EPS-) mutatók alkalmazásával, sőt néhány tanulmányban a CFP meghatározása a szervezeti tagok körében lefolytatott kérdőíves felmérések eredményein alapul (Orlitzky et al. 2003, Deckop et al. 2006, Beurden - Gössling 2008, Orlitzky 2011, Lu et al. 2014).

A társadalmi és pénzügyi teljesítmény kapcsolatát a legtöbb szerző lineáris regressziós modell segítségével vizsgálja, mely irányulhat a CSP-nek a CFP-re, vagy a CFP-nek a CSP-re gyakorolt hatásának elemzésére, de a kétirányúság kérdését is figyelembe vevő regressziós rendszerekkel (Deckop et al. 2006, Beurden - Gössling 2008, Orlitzky 2011, Lu et al. 2014) is találkozhatunk. Az egyszerű lineáris regressziós modelleket (OLS) azonban számtalan kritika éri, egyrészt azon elméleti és gyakorlati megállapítások alapján, miszerint a CSP-CFP kapcsolata sokkal inkább görbe vonalú, mintsem egyenes vonalú pályát követ (Barnett - Salomon 2006), illetve, hogy a CSPCFP közötti kapcsolat vizsgálatakor mind az ún. jó menedzsment elmélet, mind pedig az ún. erőforrás-többlet elmélet alapján az endogenitás problémáját is számításba kell venni (Waddock - Graves 1997, Schreck 2011). A szimultanitásnak és a kihagyott változóknak betudható endogenitás kezelése az egyes szakirodalmi forrásokban általában véve kétlépcsős lineáris regressziós modellek, illetve a Granger-féle oksági teszt segítségével történik (Schreck 2011; Lu et al. 2014). Természetesen a CSP-CFP kapcsolat vizsgálatával foglalkozó regressziós modellek többségébe kontrollváltozók beépítésére is sor kerül. Ilyen kontrollváltozóként jelenik meg a metaanalízist lefolytató tanulmányok (Orlitzky et al. 2003; Deckop et al. 2006; Beurden - Gössling 2008; Orlitzky 2011; Lu et al. 2014) alapján a vállalati méret, az iparág és annak speciális jellemzői, a tulajdonosi szerkezet, a tőkestruktúra-tőkeáttétel, a kockázat, a K+F-intenzitás, vagy éppen a reklámköltségek nagysága, míg a nemzetközi összehasonlítással is foglalkozó munkákban a helyi külső környezeti, makrogazdasági szempontokat tükröző kontrollváltozók, mint például a GDP növekedési üteme, az infláció alakulása, vagy éppen a népességszám alkalmazására is sor kerül. Az egyes szakirodalmi források emellett arra is figyelmeztetnek, hogy mind a CSP, mind a CFP, mind pedig a köztük lévő kapcsolat hátterében meghúzódó hatások az egyes iparágak, vállalatok és nemzetgazdaságok speciális jellemzőit figyelembe véve ágazatonként, vállalatonként, országonként akár más-más hatásmechanizmusokon keresztül, eltérő mértékben jelentkezhetnek.

A társadalmi felelősségvállalás és a pénzügyi teljesítmény kapcsolatának banki és a pénzügyi szektoron belüli vizsgálatával foglalkozó kutatások feltételezései és ered- 
ményei sem egységesek. A banki CFP mérésére a szakirodalmi források döntő többsége számviteli - tőkearányos megtérülési (pl. Soana 2011; Mozghovyi - Ratnykova 2011; Islam 2012; Marcia et al. 2013; Ofori et al. 2014), eszközarányos megtérülési (pl. Soana 2011; Mozghovyi - Ratnykova 2011; Ahmed et al 2012; Islam 2012; Marcia et al. 2013; Jo et al. 2014; Ofori et al. 2014), nettó profit (pl. Mozghovyi - Ratnykova 2011; Okwemba et al. 2014; Malik - Nadeem 2014), nettó kamatbevétel (Wu - Shen 2013), nem teljesítő hitelek aránya ( Wu - Shen 2013; Simpson - Kohers 2002) - mutatókat alkalmaz, de találhatunk példákat piaci indikátorok (Saxena-Kohli 2012; Carnevale - Mazzuca 2014; Ahmed et al. 2012) használatára is. Jelentősebb eltérés a bankok társadalmi teljesítményének mérése tekintetében tapasztalható. Ahogyan arra már az általános CSP-CFP kutatások kapcsán utaltunk, a társadalmi teljesítmény számbavételének egyik gyakoribb módja e szektor-specifikus vizsgálatok esetében is a minősítő szervezetek által kiadott CSR, vagy etikai indexek (pl. KLD, CRA, ESI ${ }^{5}, \mathrm{EIRIS}^{6}$, Asset4esg) alkalmazása (Simpson - Kohers 2002; Soana 2011; Saxena - Kohli 2012). Sok kutatás tesz kísérletet ugyanakkor saját CSP-indikátor kidolgozására (Pérez et al. 2013; Wu - Shen 2013; Mallin et al. 2014), a CSR-jelentések vizsgálatára (Rogošić 2014; Okwemba et al. 2014), a környezeti és CSR kiadások számbavételére (Mozghovyi - Ratnykova 2011; Okwemba et al. 2014; Omoro et al. 2014; Jo et al. 2014), illetve az ügyfelek, vagy szervezeti tagok körében lefolytatott kérdőíves felmérés alapján történő teljesítmény-meghatározásra (Is/am 2012; Ahmed et al. 2012; Raihan et al. 2015; Malik - Nadeem 2014; Ofori et al. 2014; Fatma et al. 2014). A CSP mérési gyakorlatok közül érdemes kiemelni a Scholtens (2008) által az etikai és CSR-indexek, illetve kérdőíves felmérések hiányosságainak, a köztük lévő - eltérő szempontok, érintetti csoportok és indikátorok alkalmazásának betudható - konzisztenciahiány felszámolásának érdekében kidolgozott, kifejezetten a bankok társadalmi teljesítményének transzparens számbavételére szolgáló keretrendszert. A Scholtens-féle keretrendszer alkalmazása egyre több kutatásban (Id. Relano - Paulet 2012; Laidroo - Sokolova 2015) érhető tetten, melynek legfőbb oka, hogy a módszer az egyes CSR- vagy etikai minősítési adatbázisokban nem szereplő bankok társadalmi teljesítményének egységes összemérését is lehetővé teszi, hiszen a CSP meghatározása ebben az esetben a nyilvánosan elérhető banki adatok alapján történik. Ahogyan azt az 1. táblázat is mutatja, a Scholtens-féle CSP-indikátor 5 kritériumból és összesen 32 indikátorból épül fel, a banki és pénzügyi szervezetek CSR-tevékenységének értékelésére vonatkozó nemzetközi ajánlásokat és elveket is figyelembe véve. Hátrányának számít azonban, hogy vizsgálati szempontjai nehezen feleltethetők meg a CSR-indexek és minősítések társadalmi, természeti, munkavállalói, közösségi, kormányzási vagy gazdasági kategóriáinak, az egyes indikátorok esetében alkalmazott 0-1-es értékelés pedig nem alkalmas a bankok teljesítményei közötti finom eltérések, illetve az egyes szempontokon belüli többletteljesítmények kimutatására.

\footnotetext{
${ }^{5}$ Környezeti Fenntarthatósági Index (Environmental Sustainability Index)

${ }^{6}$ Az EIRIS (Ethical Investment Research Services) által kidolgozott CSR-index
} 


\section{1. táblázat}

A Scholtens-féle banki társadalmi teljesítmény számbavételi keretrendszere

\begin{tabular}{|c|c|c|}
\hline Fő indikátor & Alszempont & Meghatározás módja \\
\hline \multirow{6}{*}{$\begin{array}{l}\text { I. Üzleti etika, } \\
\text { fenntarthatósági } \\
\text { jelentések }\end{array}$} & 1. Fenntarthatósági jelentés & $\begin{array}{l}\text { 0: Nem rendelkezik CSR-jelentéssel, } \\
\text { 1: Rendelkezik CSR-jelentéssel }\end{array}$ \\
\hline & $\begin{array}{l}\text { 2. ICC Business Charter for Sustainable } \\
\text { Development támogatása }\end{array}$ & $\begin{array}{l}\text { 0: Nem tartozik az ICC aláírói közé, } \\
\text { 1: Az ICC aláirói közé tartozik }\end{array}$ \\
\hline & 3. UNEP FI & $0:$ nem vette át, 1 : átvette \\
\hline & 4. Equator-elvek & $0:$ nem vette át, 1 : átvette \\
\hline & 5. Global Compact & $0:$ nem vette át, 1 : átvette \\
\hline & 6. „Who Cares Wins” & $\begin{array}{l}0: \text { nem vett részt a programban, } 1 \text { : részt vett } \\
\text { a programban }\end{array}$ \\
\hline \multirow{10}{*}{$\begin{array}{l}\text { II. Környezet- } \\
\text { menedzsment }\end{array}$} & 7. Környezetmenedzsment-rendszer (EMAS) & 0 : nem rendelkezik vele, 1 : rendelkezik vele \\
\hline & $\begin{array}{l}\text { 8. Környezetmenedzsment-rendszer } \\
\text { (ISO14001) }\end{array}$ & 0 : nem rendelkezik vele, 1 : rendelkezik vele \\
\hline & 9. Környezetvédelmi politika & 0 : nem rendelkezik vele, 1 : rendelkezik vele \\
\hline & 10. Ellátási lánc figyelembevétele & $0:$ nem veszi figyelembe, 1 : figyelembe veszi \\
\hline & $\begin{array}{l}\text { 11. Környezetvédelmi célkitűzések } \\
\text { mennyiségi meghatározása }\end{array}$ & $\begin{array}{l}0: \text { Nincsenek definiált mennyiségi célkitűzések } \\
\text { 1: Definiált mennyiségi célkitűzésekkel } \\
\text { rendelkeznek }\end{array}$ \\
\hline & $\begin{array}{l}\text { 12. Környezetvédelmi célkitűzések } \\
\text { transzparenciája }\end{array}$ & $\begin{array}{l}\text { 0: Nincsenek transzparens célok, } \\
\text { 1: Transzparens célok }\end{array}$ \\
\hline & $\begin{array}{l}\text { 13. Környezeti kockázatok figyelembevétele } \\
\text { a hitelnyújtáskor }\end{array}$ & $0:$ nem veszi figyelembe, 1 : figyelembe veszi \\
\hline & 14. Speciális szektorok kizárása & 0 nem veszi figyelembe, 1 : figyelembe veszi \\
\hline & $\begin{array}{l}\text { 15. Világbanki iránymutatás a környezeti } \\
\text { kockázatok kezelésére }\end{array}$ & $0:$ nem veszi figyelembe, 1 : figyelembe veszi \\
\hline & $\begin{array}{l}\text { 16. OESO-iránymutatás a környezeti } \\
\text { kockázatok kezelésére }\end{array}$ & $0:$ nem veszi figyelembe, 1 : figyelembe veszi \\
\hline \multirow{7}{*}{$\begin{array}{l}\text { III. Felelös pénzügyi } \\
\text { termékek }\end{array}$} & 17. Társadalmilag felelős befektetések & $0:$ nincs, 1: van \\
\hline & 18. Társadalmilag felelős megtakarítások & 0: nincs, 1: van \\
\hline & 19. Fenntartható finanszírozás & 0: nincs, 1: van \\
\hline & 20. Mikrohitelezés & 0: nincs, 1: van \\
\hline & 21. Környezetvédelmi tanácsadás & $0:$ nincs, 1: van \\
\hline & 22. Klímatermékek & 0: nincs, 1: van \\
\hline & 23. Egyéb fenntarthatósági termékek & 0: nincs, 1: van \\
\hline \multirow{6}{*}{$\begin{array}{l}\text { IV. Társadalmi } \\
\text { tevékenység }\end{array}$} & 24. Szponzorálás & $0:$ nem, 1 : igen \\
\hline & 25. Közösségi tevékenység & $0:$ nem, 1: igen \\
\hline & 26. Tréning és oktatás & $0:$ nincs, 1: van \\
\hline & 27. Diverzitás és lehetőségek & $0:$ nem veszi figyelembe, 1 : figyelembe veszi \\
\hline & 28. Munkavállalói visszajelzések & 0: nincs, 1: van \\
\hline & 29. Üzleti etika & 0: nincs, 1: van \\
\hline \multirow[t]{4}{*}{ V. Benchmarking } & 30. Dow Jones Sustainability Index & $0:$ nem szerepel rajta, 1 : szerepel rajta \\
\hline & 31. FTSE4Good & $0:$ nem szerepel rajta, 1 : szerepel rajta \\
\hline & 32. Domini Social Index & $0:$ nem szerepel rajta, 1 : szerepel rajta \\
\hline & 33. ESI Europe & $0:$ nem szerepel rajta, 1 : szerepel rajta \\
\hline
\end{tabular}

Forrás: Scholtens (2008: 165) alapján 
A banki szektorra fókuszáló forrásokban alkalmazott módszertant tekintve megállapítható, hogy a CFP és CSP kapcsolatának elemzése a nem szektorspecifikus elemzésekhez hasonlóan általában korreláció-elemzés, illetve lineáris regreszsziós elemzés segítségével történik, csak néhány tanulmány (Wu - Shen 2013; Mallin et al. 2014; Jo et al. 2014) törekszik az endogenitás problematikájának számbavételére. A regressziós modellek leggyakrabb előforduló kontrollváltozójának a banki CSP-CFP vizsgálatoknál is a szervezeti méret, a szervezet alapítása óta eltelt idő, a tulajdonosi struktúra mutatók számítanak, de a bankok speciális teljesítményjellemzőit is figyelembe vevő CAMELS alapú tőkemegfelelési, eszközminőségi, fedezeti és likviditási mutatókra is találhatunk példákat (Simpson - Kohers 2002; Wu -Shen 2013; Mallin et al. 2014; Jo et al. 2014). A tőkemegfelelési mutató a szolvens és hatékony banki múködés alapvető feltételét, a tőke hatékony kezelését veszi számításba, hiszen a saját tőke garantálja hosszú távon a bank fizetőképességét és a potenciálisan bekövetkező kedvezőtlen események korrigálását. Az eszközminőség a banki eszközállomány legnagyobb részét kitevő, ügyfelekkel, hitelintézetekkel és egyéb külső felekkel szembeni követelések, azaz kintlévőségek behajtási kockázatának megfelelő minőségi szintet jelöli meg. A menedzsmenthatékonyság, azaz az adminisztratív költségek és az összes eszköz hányadosából adódó mutató veszi számításba a menedzsmenttel szemben támasztott, a belső érdekkonfliktusok feloldásával, a szervezetet jól átláthatóvá, ellenőrizhetővé tételével, a bank hatékonyságának növelésével és a múködési kockázatok csökkentésével kapcsolatos tevékenységeket, míg a likvid bankok a rendelkezésükre álló, kellő nagyságú likvid eszköz révén a velük szemben fellépő követeléseknek bármikor eleget tudnak tenni.

A banki CSP-nek a CFP-re gyakorolt hatását tekintve összességében véve kijelenthető, hogy míg egyes tanulmányok (Bolton 2012; Simpson - Kohers 2002; Mallin et al. 2014; Wu - Shen 2013; Islam 2012; Marcia et al. 2013) a CSP-nek a CFP-re gyakorolt pozitív hatását tárták fel, vagy nem tudtak egyértelmú kapcsolatot kimutatni a társadalmi és a pénzügyi teljesítmény között (pl. Das et al. 2015; Soana 2011; Mozghovyi - Ratnykova 2011; Ahmed et al. 2012; Raihan et al. 2015; Malik - Nadeem 2014), a vizsgált banki kutatások egyike sem igazolta a bankok társadalmi teljesítményének pénzügyi teljesítményre gyakorolt negatív hatását. Összességében véve tehát jelenthető ki, hogy a bankspecifikus CSP-CFP vizsgálatok a teljesítménymutatók meghatározása, az alkalmazott módszertan, az elemzéseknél figyelembe vett változók tekintetében erősen támaszkodnak a nem szektorspecifikus elemzésekre, miközben törekednek az ágazat speciális jellemzőinek beépítésére is.

\section{A társadalmi és pénzügyi teljesítmény kapcsolata hét hazai bank mintáján}

Az előző fejezet megállapításai alapján elemzésünkben arra keressük a választ, hogy milyen kapcsolat mutatható ki a társadalmi és a pénzügyi teljesítmény között a hazai bankszektorban a 2006-2013-as időszakban domináns részesedéssel bíró, a Magyar 
Nemzeti Bank mint felügyeleti szerv besorolása szerinti részvénytársasági formában múködő hét ${ }^{7}$ bank esetében. Az azonos múködési formán túl a hét bank kiválasztása mellett szól, hogy a vizsgálat teljes időszakában jelen voltak és meghatározó piaci részesedéssel bírtak a hazai piacon, CSR-tevékenységeikre pedig visszamenőleg is rendelkezésre állnak nyilvános információk. A vizsgált időszak alatt így összesen 56 bank-évvel számolhattunk. A bankok társadalmi és pénzügyi teljesítményének kapcsolatát a teljes mintára elkészített regresszióanalízis, illetve kétlépcsős lineáris regressziós elemzés segítségével vizsgáltuk, melyben az SPSS 22.0 statisztikai elemző szoftver nyújtott segítséget. A bankok társadalmi és pénzügyi teljesítménye közötti kapcsolat vizsgálatával foglalkozó szakirodalmi források alapján a pénzügyi és társadalmi teljesítmény kapcsolatát leíró regressziós modellek főbb elemeit a 2. táblázatban foglaltuk össze.

\section{2. táblázat}

\section{A regressziós és kétlépcsős lineáris regressziós modell változói}

\begin{tabular}{|c|c|c|}
\hline Változó neve & Változó mérése & Adatok forrása \\
\hline \multicolumn{3}{|l|}{ Függő változó(k) } \\
\hline NI & Nettó profit & Éves beszámolók \\
\hline AROE & $\begin{array}{l}\text { Adózott jövedelem/ Átlagos sajáttőke- } \\
\text { állomány }\end{array}$ & Éves beszámolók \\
\hline AROA & $\begin{array}{l}\text { Adózott jövedelem/ Átlagos } \\
\text { eszközállomány }\end{array}$ & Éves beszámolók \\
\hline \multicolumn{3}{|l|}{ Független változók } \\
\hline CSP1 & $\begin{array}{l}\text { Scholtens-féle banki társadalmi } \\
\text { teljesítmény mutató }\end{array}$ & $\begin{array}{l}\text { CSR jelentések, banki } \\
\text { weboldalak }\end{array}$ \\
\hline CSP2 & $\begin{array}{l}\text { Módosított Scholtens-féle banki } \\
\text { társadalmi teljesítmény mutató }\end{array}$ & $\begin{array}{l}\text { CSR jelentések, banki } \\
\text { weboldalak }\end{array}$ \\
\hline \multicolumn{3}{|l|}{ Kontroll változók } \\
\hline Tőkemegfelelés (CA) & Saját tőke/Összes eszköz & Éves beszámolók \\
\hline Eszközminőség (AQ) & $\begin{array}{l}\text { Kockázati céltartalék és értékvesztés/ } \\
\text { Saját tőke }\end{array}$ & Éves beszámolók \\
\hline Menedzsment hatékonyság (ME) & Működési kiadások/Összes eszköz & Éves beszámolók \\
\hline Likviditás-fedezettség (LC) & $\begin{array}{l}\text { Hitelek/(Betétek+Rövid lejáratú saját } \\
\text { kibocsátású eszközök) }\end{array}$ & Éves beszámolók \\
\hline Likviditás (LI) & $\begin{array}{l}\text { (Pénzeszközök+Monetáris betétek)/ } \\
\text { Összes eszköz }\end{array}$ & Éves beszámolók \\
\hline Méret (FS) & $\begin{array}{l}\text { Összes eszköz természetes alapú } \\
\text { logaritmusa }\end{array}$ & Éves beszámolók \\
\hline
\end{tabular}

\footnotetext{
${ }^{7}$ Budapest Bank, CIB Bank, Erste Bank, Kereskedelmi és Hitelbank, MKB Bank, OTP Bank és Raiffeisen Bank
} 
Ahogyan az a 2. táblázatból kiolvasható, regressziós modelljeinkben a függő változóként értelmezett pénzügyi teljesítmény számviteli mutatók, azaz átlagos sajáttőke-arányos nyereség (AROE) és átlagos eszközarányos nyereség (AROA) segítségével került kifejezésre. A nettó jövedelem mint függő változó alkalmazását azért tartottuk fontosnak, mert ahogyan arra Barnett és Salomon (2012:1309) is figyelmeztetnek, a rátákban kifejezett függő változók alkalmazása az eredmények torzulását, a kapcsolatok bonyolítását is okozhatja, hiszen esetükben a független változók a nevezőre, a számlálóra, vagy akár mindkettőre hatással lehetnek.

A bankok társadalmi teljesítményének számbavételét - a minősítő szervezetek által meghatározott CSR-indexek hiányában - Scholtens (2008) keretrendszerére támaszkodva kétféleképpen végeztük el. Elsőként Laidroo és Sokolova (2015) alapján a Scholtens-féle keretrendszer 29 indikátorára építve határoztuk meg az egyes bankok évenkénti átlagteljesítményét (CSP1). Majd a scholtensi modell kritériumainak módosítása alapján is meghatároztuk az egyes bankok társadalmi teljesítményét (CSP2). A módosított scholtensi modellben (3. táblázat) az alapmodell fö- és alkritériumainak körét úgy alakítottuk át, hogy az alkalmas legyen a korábbi - a munkavállalói szempontok érvényesítésével, a CSR stratégiai-szervezeti beépülésének vizsgálatával, illetve a közvetett és közvetlen társadalmi szerepvállalás szétválasztásával kapcsolatos - hiányosságok feloldására, illetve törekedtünk az eredeti modellben szereplő, de a hazai bankok szempontjából kevéssé releváns, illetve adatok hiányában figyelembe nem vehető változóinak a mellőzésére. Mindkét társadalmiteljesítmény-mutató az egyes bankok, esetenként anyavállalatuk éves beszámolóiban, saját CSR- vagy fenntarthatósági jelentéseiben, illetve weboldalain közölt információkra építve, a vizsgált időszak valamennyi évére, átlagszámítás alapján került meghatározásra (4. táblázat). 


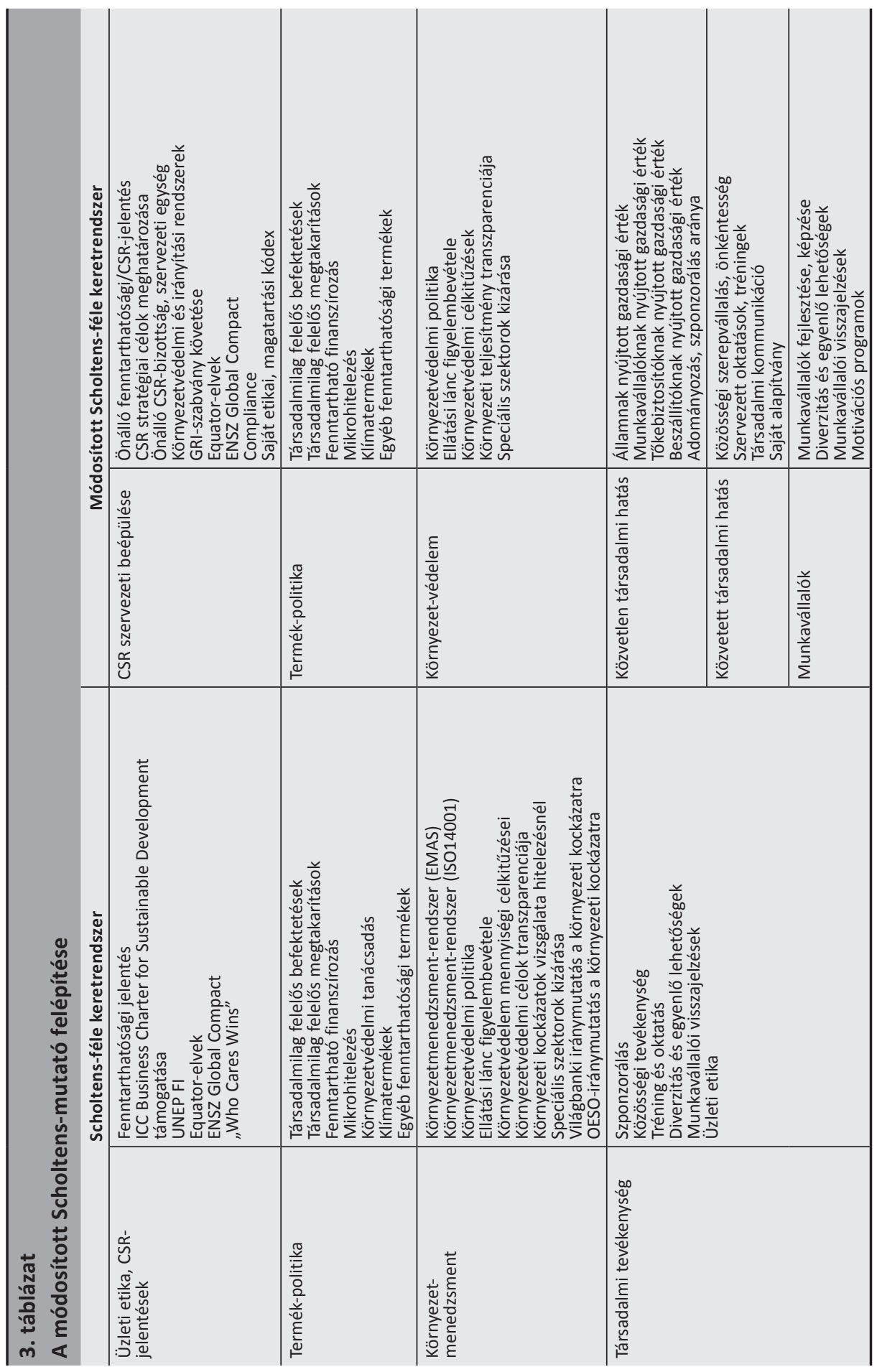


A regressziós modellek kontrollváltozóit, a szektorspecifikus kutatások alapján a hitelintézeti teljesítmény vizsgálatát szolgáló CAMELS-modell elemeiből választottuk meg, míg a vállalati méret hatásainak számbavétele az összes eszköz természetes alapú logaritmusában kifejezett szervezeti méret (FS) mutatóval történt. A pénzügyiteljesítmény-mutatók és a kontrollváltozók értékeit a bankok éves beszámolóira, illetve az MNB éves Aranykönyveire támaszkodva határoztuk meg.

\begin{tabular}{|c|c|c|c|c|c|c|c|c|c|c|c|c|c|c|c|c|}
\hline \multicolumn{17}{|c|}{$\begin{array}{l}\text { 4. táblázat } \\
\text { CSP1- és CSP2-érté } \\
\text { (adatok százalékban) }\end{array}$} \\
\hline & \multicolumn{8}{|c|}{ CSP1 } & \multicolumn{8}{|c|}{ CSP2 } \\
\hline & 2006 & 2007 & 2008 & 2009 & 2010 & 2011 & 2012 & 2013 & 2006 & 2007 & 2008 & 2009 & 2010 & 2011 & 2012 & 2013 \\
\hline 1 & 16,67 & 20,24 & 23,81 & 23,81 & 27,98 & 32,14 & 32,14 & 27,98 & 14,64 & 21,38 & 24,91 & 24,19 & 37,15 & 41,39 & 41,63 & 32,58 \\
\hline 2 & 31,67 & 31,67 & 50,48 & 59,64 & 62,14 & 62,14 & 62,14 & 62,14 & 45,71 & 47,17 & 63,89 & 67,62 & 67,74 & 69,36 & 69,43 & 69,44 \\
\hline 3 & 25,00 & 25,00 & 25,00 & 20,83 & 28,57 & 28,57 & 36,07 & 36,07 & 9,95 & 18,09 & 19,61 & 21,95 & 28,99 & 28,99 & 38,99 & 39,01 \\
\hline 4 & 47,98 & 47,98 & 55,48 & 55,48 & 64,64 & 68,21 & 68,21 & 68,21 & 45,88 & 50,76 & 63,43 & 61,67 & 73,73 & 75,56 & 75,95 & 75,86 \\
\hline 5 & 8,33 & 8,33 & 43,81 & 43,81 & 46,31 & 46,31 & 32,14 & 32,14 & 18,47 & 13,86 & 56,66 & 59,09 & 62,86 & 62,87 & 40,42 & 40,34 \\
\hline 6 & 47,38 & 47,38 & 49,88 & 53,45 & 53,45 & 53,45 & 53,45 & 53,45 & 38,99 & 62,43 & 66,91 & 67,98 & 68,31 & 68,28 & 68,29 & 68,47 \\
\hline 7 & 16,67 & 16,67 & 32,50 & 32,50 & 32,50 & 32,50 & 31,07 & 31,07 & 9,83 & 13,84 & 38,49 & 36,82 & 36,99 & 28,98 & 28,96 & 32,38 \\
\hline
\end{tabular}

A vizsgált adatokra lefuttatott regressziós tesztek alapján a függő és független változók kapcsolata leginkább lineáris regressziós egyenlet segítségével írható le, mely a vizsgálatba vont változók (Id. 2. táblázat) alapján az alábbi általános formát ölti:

$$
\mathrm{CFP}_{\mathrm{i}}=\beta_{1} \mathrm{CSP}_{\mathrm{i}}+\beta_{2} \mathrm{CA}_{\mathrm{i}}+\beta_{3} \mathrm{AQ}_{\mathrm{i}}+\beta_{4} \mathrm{ME}_{\mathrm{i}}+\beta_{5} \mathrm{LC}_{\mathrm{i}}+\beta_{6} \mathrm{LI}_{\mathrm{i}}+\beta_{7} \mathrm{FS}_{\mathrm{i}}+\varepsilon
$$

Az 5. táblázat a robusztus lineáris regressziós elemzések eredményeit összegzi a nettó jövedelem, az átlagos sajáttőke-megtérülés és az átlagos eszközmegtérülés tekintetében az egyes társadalmi teljesítményindikátorok esetében. A regressziók során White-féle robosztus standard hibákat alkalmaztunk. Ahogyan az a táblázatból kiolvasható, a Scholtens-féle társadalmi teljesítmény indikátor (CSP1) alkalmazása esetében a többszörös korrelációs koefficiens értékei $\left(r_{\mathrm{NI}}=0,803, r_{\mathrm{AROE}}=0,732, r_{\mathrm{AROA}}=0,748\right)$ a függő és a független változók közötti lineáris összefüggés közepes-erős szorosságát mutatják. A többszörös determinációs koefficiensek $\left(R^{2}\right)$ értékei alapján kijelenthető, hogy a nettó jövedelem szóródásának 64,5 százaléka, az átlagos sajáttőke-arányos megtérülés szóródásának 58,7 százaléka, míg az átlagos eszközarányos megtérülés 60,8 százaléka magyarázható a független változók változásával. Hasonló értékeket figyelhetünk meg a társadalmi teljesítmény módosított Scholtens-féle (CSP2) mutatójának alkalmazása esetén is, azzal a megjegyzéssel, hogy ezen modellek esetében nő a függő és független változók közötti lineáris összefüggés szorossága, és erősebb a független változók magyarázó ereje is. Ugyanakkor azt is meg kell jegyezni, hogy 
valamennyi függő változó változására más, jelen vizsgálatba be nem vont tényezők is hatnak, illetve hogy a vizsgálat lefolytatását érdemes nagyobb időintervallum figyelembevételével is elvégezni.

\begin{tabular}{|c|c|c|c|c|c|c|}
\hline \multicolumn{7}{|c|}{$\begin{array}{l}\text { A lineáris regressziós modellek összefoglaló táblázata - NI, AROE, AROA függő } \\
\text { változók és CSP1, CSP2 független változók esetében }\end{array}$} \\
\hline & \multicolumn{3}{|c|}{ CSP1 esetén } & \multicolumn{3}{|c|}{ CSP2 esetén } \\
\hline & NI & AROE & AROA & NI & AROE & AROA \\
\hline $\mathrm{R}$ & 0,803 & 0,732 & 0,748 & 0,813 & 0,751 & 0,762 \\
\hline $\mathrm{R}^{2}$ & 0,645 & 0,587 & 0,608 & 0,660 & 0,589 & 0,617 \\
\hline Adjusted R Square & 0,593 & 0,526 & 0,551 & 0,611 & 0,529 & 0,561 \\
\hline
\end{tabular}

A regressziós koefficiensek pénzügyi teljesítményt befolyásoló hatásait vizsgálva (6. táblázat) kijelenthetjük, hogy igazolást nyert a társadalmi teljesítmény (CSP1 és CSP2), az eszközminőség (AQ) és a likviditásfedezettség (LC) nettó jövedelemre gyakorolt negatív, illetve a méret (FS) esetében pozitív hatása, míg a menedzsmenthatékonyság ( $\mathrm{ME}$ ) és a likviditás (LI) hatása nem bizonyítható. A módosított Scholtens-indikátor esetén a tőkemegfelelés (CA) nettó jövedelemre való gyenge pozitív hatása azonosítható. Az átlagos sajáttőke-alapú megtérülés (AROE) esetében az eszközminőség szignifikáns negatív hatása mindkét lineáris regressziós modell esetében igazolást nyert a likviditásfedezettség gyenge hatása mellett. A társadalmi teljesítmény ROE-ra gyakorolt negatív hatása csupán a módosított Scholtens-féle (CSP2) indikátort tartalmazó regressziós modell esetén fogadható el. Az átlagos eszközmegtérülési mutató alkalmazása esetében is igazolást nyert az eszközminőség mint kontrolltényező negatív hatása, ugyanakkor míg a társadalmi teljesítmény negatív hatását a Scholtens-féle (CSP1) indikátor alkalmazása esetében nem sikerült bizonyítani, a módosított Scholtens (CSP2)-indikátor használatával már igazolást nyert a társadalmi teljesítmény eszközmegtérülést rontó hatása. 


\section{6. táblázat}

\section{Koefficiensek a Scholtens-féle CSP1 és a módosított Scholtens-féle CSP2}

figyelembevételével - minden tényezővel

\begin{tabular}{|c|c|c|c|}
\hline \multirow{2}{*}{$\begin{array}{l}\text { FÜGGETLEN } \\
\text { VÁLTOZÓ }\end{array}$} & \multicolumn{3}{|c|}{ FÜGGŐ VÁLTOZÓ } \\
\hline & NETTÓ PROFIT & AROE & AROA \\
\hline \multicolumn{4}{|c|}{ Scholtens-féle társadalmi teljesítmény esetén } \\
\hline $\begin{array}{l}\text { Constant } \\
\text { (Std. Error) }\end{array}$ & $\begin{array}{c}-484603 * * \\
(192894)\end{array}$ & $\begin{array}{c}2,73451 \\
(1,99880)\end{array}$ & $\begin{array}{c}0,0717541 \\
(0,0971166)\end{array}$ \\
\hline CSP1 & $\begin{array}{c}-86006,1^{*} \\
(45397,8)\end{array}$ & $\begin{array}{c}-0,1016 \\
(0,326682)\end{array}$ & $\begin{array}{l}-0,0288578 \\
(0,0206855)\end{array}$ \\
\hline CA & $\begin{array}{c}265948 \\
(184011) \\
\end{array}$ & $\begin{array}{c}-1,47886 \\
(0,962617)\end{array}$ & $\begin{array}{l}0,00942178 \\
(0,0690040)\end{array}$ \\
\hline$A Q$ & $\begin{array}{c}-38128,5 * * * \\
(7622,84)\end{array}$ & $\begin{array}{c}-0,417082^{* * *} \\
(0,0641854)\end{array}$ & $\begin{array}{c}-0,0218310 * * * \\
(0,00305243)\end{array}$ \\
\hline ME & $\begin{array}{c}399423 \\
(435347)\end{array}$ & $\begin{array}{l}0,467713 \\
(2,05843) \\
\end{array}$ & $\begin{array}{l}0,0462294 \\
(0,149819) \\
\end{array}$ \\
\hline LC & $\begin{array}{c}-48543,3^{* *} \\
(20416)\end{array}$ & $\begin{array}{c}-0,393224^{*} \\
(0,211651)\end{array}$ & $\begin{array}{c}-0,0240745^{* *} \\
(0,0105019)\end{array}$ \\
\hline $\mathrm{LI}$ & $\begin{array}{c}8355 \\
(8485,57) \\
\end{array}$ & $\begin{array}{c}0,0501049 \\
(0,0587081)\end{array}$ & $\begin{array}{c}0,00362491 \\
(0,00349325)\end{array}$ \\
\hline FS & $\begin{array}{c}39421,1 * * * \\
(12581,7)\end{array}$ & $\begin{array}{l}-0,123892 \\
(0,121207)\end{array}$ & $\begin{array}{l}-0,00107046 \\
(0,00610950)\end{array}$ \\
\hline \multicolumn{4}{|c|}{ Módosított Scholtens-féle társadalmi teljesítmény esetén } \\
\hline $\begin{array}{l}\text { Constant } \\
\text { (Std. Error) }\end{array}$ & $\begin{array}{c}-536127^{* *} \\
(202106) \\
\end{array}$ & $\begin{array}{c}2,55206 \\
(2,10045)\end{array}$ & $\begin{array}{l}0,0564608 \\
(0,101774)\end{array}$ \\
\hline CSP2 & $\begin{array}{c}-89941,2 * * \\
(42230,7) \\
\end{array}$ & $\begin{array}{c}-0,159699^{*} \\
(0,311049)\end{array}$ & $\begin{array}{c}-0,0293010^{*} \\
(0,0184572)\end{array}$ \\
\hline CA & $\begin{array}{l}357614^{*} \\
(203101)\end{array}$ & $\begin{array}{l}-1,30930 \\
(1,12531)\end{array}$ & $\begin{array}{c}0,0391734 \\
(0,0775070)\end{array}$ \\
\hline$A Q$ & $\begin{array}{c}-36623,2^{* * * *} \\
(7695,08)\end{array}$ & $\begin{array}{c}-0,414654^{* * *} \\
(0,0666511)\end{array}$ & $\begin{array}{c}-0,0214430 * * * \\
(0,00313394)\end{array}$ \\
\hline $\mathrm{ME}$ & $\begin{array}{c}296506 \\
(417520) \\
\end{array}$ & $\begin{array}{c}0,30629 \\
(1,88541) \\
\end{array}$ & $\begin{array}{l}0,0123526 \\
(0,146053)\end{array}$ \\
\hline LC & $\begin{array}{c}-48394,7 * * \\
(20706,5)\end{array}$ & $\begin{array}{c}-0,395319^{*} \\
(0,213633)\end{array}$ & $\begin{array}{c}-0,0239875^{* *} \\
(0,015357)\end{array}$ \\
\hline $\mathrm{LI}$ & $\begin{array}{c}7425,28 \\
(7800,60) \\
\end{array}$ & $\begin{array}{l}-0,0485320 \\
(0,0565713) \\
\end{array}$ & $\begin{array}{c}0,00332075 \\
(0,00328560) \\
\end{array}$ \\
\hline FS & $\begin{array}{c}43192,2 * * * \\
(13174,2)\end{array}$ & $\begin{array}{l}-0,109529 \\
(0,128009)\end{array}$ & $\begin{array}{l}3,23360 \mathrm{e}-05 \\
(0,00640038)\end{array}$ \\
\hline
\end{tabular}




\begin{tabular}{|c|c|c|c|}
\hline \multicolumn{4}{|l|}{$\begin{array}{l}\text { 7. táblázat } \\
\text { Koefficiense } \\
\text { figyelembev }\end{array}$} \\
\hline \multirow{2}{*}{$\begin{array}{l}\text { FÜGGETLEN } \\
\text { VÁLTOZÓ }\end{array}$} & \multicolumn{3}{|c|}{ FÜGGŐ VÁLTOZÓ } \\
\hline & NETTÓ PROFIT & AROE & AROA \\
\hline \multicolumn{4}{|c|}{ Scholtens-féle társadalmi teljesítmény esetén } \\
\hline $\begin{array}{l}\text { Constant } \\
\text { (Std. Error) }\end{array}$ & $\begin{array}{c}-352759 * * \\
(168385)\end{array}$ & $\begin{array}{c}0,558785^{* * * *} \\
(0,179271)\end{array}$ & $\begin{array}{c}0,0436536 * * * \\
(0,00932544)\end{array}$ \\
\hline CSP1 & $\begin{array}{c}-81116,1^{*} \\
(43428,7)\end{array}$ & & \\
\hline$A Q$ & $\begin{array}{c}-43821,6 * * * \\
(6101,28) \\
\end{array}$ & $\begin{array}{c}-0,377446 * * * \\
(0,0542081)\end{array}$ & $\begin{array}{c}-0,0217175 * * * \\
(0,00250649)\end{array}$ \\
\hline LC & $\begin{array}{c}-72160,0 * * * \\
(19279,7)\end{array}$ & $\begin{array}{c}-0,237039 * \\
(0,141556)\end{array}$ & $\begin{array}{c}-0,0202774 * * * \\
(0,00731349)\end{array}$ \\
\hline FS & $\begin{array}{c}35589,8 * * * \\
(11864,8)\end{array}$ & & \\
\hline \multicolumn{4}{|c|}{ Módosított Scholtens-féle társadalmi teljesítmény esetén } \\
\hline $\begin{array}{l}\text { Constant } \\
\text { (Std. Error) }\end{array}$ & $\begin{array}{c}-509119 * * \\
(190964)\end{array}$ & $\begin{array}{c}0,558785 * * * \\
(0,179271)\end{array}$ & $\begin{array}{c}0,0436536 * * * \\
(0,00932544)\end{array}$ \\
\hline CSP2 & $\begin{array}{c}-91766,0 * * \\
(41635,2)\end{array}$ & $\begin{array}{c}-0,11977425^{*} \\
(0,23926846)\end{array}$ & $\begin{array}{c}-0,02197575^{*} \\
(0,0184572)\end{array}$ \\
\hline$C A$ & $\begin{array}{l}425051 * * \\
(161974)\end{array}$ & & \\
\hline$A Q$ & $\begin{array}{c}-35919,3 * * * \\
(7181,52)\end{array}$ & $\begin{array}{c}-0,377446 * * * \\
(0,0542081)\end{array}$ & $\begin{array}{c}-0,0217175^{* * *} \\
(0,00250649)\end{array}$ \\
\hline LC & $\begin{array}{c}-51052,0 * * * \\
(18155,9)\end{array}$ & $\begin{array}{c}-0,237039 * \\
(0,141556)\end{array}$ & $\begin{array}{c}-0,0202774 * * * \\
(0,00731349)\end{array}$ \\
\hline FS & $\begin{array}{c}42288,4 * * * \\
(12850,9)\end{array}$ & & \\
\hline
\end{tabular}

Mivel a magyarázó változók nagy része az eredeti regressziós eredményekben (6. táblázat) nem mutatott szignifikáns kapcsolatot, ezért egy újabb robusztus regresszióanalízist lefuttatva már csak a szignifikáns tényezőket adtuk meg magyarázó változónak (7. táblázat). Mivel az eredetileg, majd a kihagyott változókkal futtatott regresszió eredményében a független változók hatásának tekintetében nincs releváns nagyságrendi különbség, kijelenthető, hogy a szignifikáns változók és a másodlagosan futtatott regresszióból kihagyott paraméterek között számottevő korreláció nem fedezhető fel (nincs multikollinearitás), így a becslésünk nem torzított (Rádóczy 2017).

A nettó jövedelem tekintetében mindkét társadalmi indikátorral lefuttatott vizsgálat megerősítette az összes tényezővel végzett lineáris regressziós elemzések eredményeit. A Scholtens-féle indikátor esetén a likviditásfedezettség nettó jövedelemre 
való negatív hatása erősebbé vált, a módosított Scholtens-féle indikátor esetében pedig szintén sikerült igazolni a tőkemegfelelés pozitiv és a likviditásfedezettség negatív irányú hatását a nettó jövedelemre. Az átlagos sajáttőke-megtérülés vonatkozásában szignifikáns tényezőkkel elvégzett robusztus regressziós vizsgálat alapján is negatív kapcsolat mutatható ki az átlagos sajáttőke-megtérülésként értelmezett pénzügyi teljesítmény és az eszközminőség, illetve a likviditás-fedezettség között, illetve igazolást nyert a CSP2-ben kifejezett társadalmi teljesítmény AROE-ra gyakorolt negatív hatása. Az átlagos eszközmegtérülés tekintetében igazolt a CSP2ben kifejezett társadalmi felelősség ROA-ra gyakorolt negatív hatása csakúgy, mint a kontrollváltozóként figyelembe vett eszközminőségnek és likviditásfedezettségnek a szignifikáns negatív hatása.

\section{Fő következtetések}

Az utóbbi évtizedben olyan gazdasági és szektorbeli változások és hatásmechanizmusok indultak el, amelyek a hazai bankszektorban is új versenyhelyzethez és piaci átrendeződéshez vezettek. Leglényegesebb következményként a biztonságos tőkemegfelelést célzó, - a magyar számviteli szabályok mellett - a Bázeli Bizottság által definiált irányelvek és mutatók jelentek meg, amelyek a magyar bankokra 2008. januári hatállyal érvényesek. A Bázel III. szabályozásban a tőkeáttétel fogalma módosult, bevezetésre került az anticiklikus tőkepuffer, valamint szigorodott a tőke számítása is (Tier1 mutató $\left.{ }^{8}\right)$. A tókepuffer bevezetésének következményeképpen hosszú távon a tőkemegfelelési mutató elvárt szintje is emelésre kerül. Az Európai Bankhatóság 2012. júniustól a rendszerkockázat szempontjából fontos pénzügyi intézményektől elvárja a 9 százalékos tőkemegfelelési mutatót. A kockázatkezelési módszereket és irányelveket a hitelezéshez kapcsolódó kötelezettségekre képzett céltartalék egészíti ki. Ez a céltartalék és a saját tőke hitelállomány-fedezettségi képessége azért játszik jelentős gyakorlati szerepet, mert az MNB 2013-ban elindított Növekedési Hitelprogramja megnövelte a banki hitelállományt. Az eszközminőség tehát a kintlévőségek behajtási kockázatának megfelelő minőségi szintet jelzi, hiszen a pénzügyi válság kezdete óta a nemteljesítési arány nagymértékben megnőtt a bankszektorban, értékében csökkenés csak visszafogottan tapasztalható.

Bár kutatásunk nem terjed ki a hazai bankszektor egészére, és ellentmond a nemzetközi banki tanulmányok eredményeinek, egyértelmúen bizonyítja, hogy a magyar bankrendszer fő szereplői részéről jellemzően a termékpolitikában megjelenő támogatott hitelek és mikrohitelek, valamint a társadalmi tevékenységben a szponzorálás, oktatás, alapítványi tevékenységként megjelenő széleskörú társadalmi felelősségvállalás olyan válaszreakció volt az utóbbi évtized globális pénzügyi válsága és a piaci térvesztés okozta következményekre, amely - az ügyfélmegtartást előtérbe helyez-

\footnotetext{
${ }^{8}$ Tier1 mutató = Alapvető tőkeelemek / Kockázatokkal súlyozott eszközérték Tőke-megfelelési mutató = Szavatoló tőke / Kockázatokkal súlyozott eszközérték
} 
ve, a szigorú szabályozási korlátokat betartva - negatívan hatott mind a jövedelmi, mind a sajáttőke- és eszközmegtérülési eredményekre is. Ezek a rövid távon vizsgált negatív megtérülési hatású tényezők azonban hosszú távon megtérülhetnek, hiszen sikerült igazolni, hogy a tőkemegfelelésnek pozitív a hatása a nettó jövedelemre. Igaz, ez azt is feltételezi, hogy hosszú távon sikerül fenntartani a tőkemegfelelést úgy, hogy a hitelportfólió növelésével és minőségének javításával, jobb kockázatkezelés mellett ér el a bankrendszer jobb jövedelmezőséget. A sajáttőke-arányos jövedelmezőségre rövid távon egyértelmúen negatív hatással van a szabályozási korlátok miatt megnövekedett tartalékigényes működés, az eszközminőség javulása mögött rejlő hitelportfólió átminősítése, átstrukturálása, komolyabb kockázatkezelése és a likviditás-fedezettséget javító Növekedési Hitelprogram eredményessége, amelyet sajnálatosan még eredményesebbnek mutat a betétgyűjtés visszaszorulása az alternatív megtakarítási termékek (pl. unit linked) előretörése miatt. Ez utóbbi két tényező negatív hatással van az eszközarányos megtérülésre is, és bár a társadalmi felelősség és teljesítmény rövid távon ugyancsak negativan befolyásolja a ROA értékét, mégis segít helyreállítani azt a bizalmi viszonyt, amely a válság során elveszett a bank-ügyfél kapcsolatból. Hosszú távon pedig az ügyfélbázis lesz az a tényező, amely a bankok fennmaradását, piaci versenyképességét és jövedelmezőségének növekedését elősegítheti egy biztonságosabb, jobb kockázatkezelési bázisra építve.

\section{Felhasznált irodalom}

Ackermann, F. - Eden, C. (2011): Strategic Management of Stakeholders: Theory and Practice, Long Rang Planning, 44(3): 179-196. https://doi.org/10.1016/j.Irp.2010.08.001

Ahmed, S.U. - Islam, Z. - Hasan, I. (2012): Corporate social responsibility and financial performance linkage. Journal of Organizational Management, 1(1): 14-21.

Barnett, M.L. - Salomon, R.M. (2006): Beyond dichotomy: The curvilinear relationship between social responsibility and financial performance. Strategic Management Journal, 27(11): 1101-1122. https://doi.org/10.1002/smj.557

Barnett, M.L. - Salomon, R.M. (2012): Does it pay to be really good? Addressing the shape of the relationship between social and financial performance. Strategic Management Journal, 33(11): 1304-1320. https://doi.org/10.1002/smj.1980

Bassen, A. - Meyer, K. - Schlange, J. (2006): The influence of corporate responsibility on the cost of capital. https://doi.org/10.2139/ssrn.984406

Beurden, van, P. - Gössling, T. (2008): The Worth of Values - A Literature Review on the Relation Between Corporate Social and Financial Performance. Journal of Business Ethics, 82(2): 407-424. https://doi.org/10.1007/s10551-008-9894-x 
Bolton, B. (2012): Corporate Social Responsibility and Bank Performance. https://papers. ssrn.com/sol3/papers.cfm?abstract_id=2277912. Letöltve: 2015. június 20.

Borzán Anita - Lentner Csaba - Szigeti Cecília (2011): Pénzügyi vállalkozások felelösségvállalásának új dimenziói. Economica, 4(11): 22-30.

Brammer, S. - Millington, A. (2008): Does it pay to be different? An analysis of the relationship between corporate social and financial performance. Strategic Management Journal, 29(12): 1325-1343. https://doi.org/10.1002/smj.714

Brammer, S. - Pavelin, S. (2006): Corporate reputation and social performance: the importance of fit. Journal of Management Studies, 43 (3): 436-456. https://doi.org/ 10.1111/j.1467-6486.2006.00597.x

Carnevale, C. - Mazzuca, M. (2014): Sustainability report and bank valuation: evidence from European stock markets. Business Ethics: A European Review, 23(1): 69-90. https://doi.org/ 10.1111/beer.12038

Chomvilailuk, R. - Butcher, B. (2013): The effect of CSR knowledge on customer liking, across cultures. International Journal of Bank Marketing, 31(2): 98-114. https://doi.org/ $10.1108 / 02652321311298672$

Das, S. - Dixon, R. - Michael, A. (2015): Corporate social responsibility reporting: a longitudinal study of listed banking companies in Bangladesh. World review of business research, 5(1): 130-154.

Deckop, J. - Merriman, K. - Gupta, S. (2006): The effects of CEO pay structure on corporate social performance. Journal of Management, 32(3): 329-342. https://doi.org/ $10.1177 / 0149206305280113$

Deutsch Nikolett (2011): A technológiai rendszerek innovációja. Az elosztott villamosenergiatermelési technológiák fenntarthatósági értékelése és rendszerinnovációs potenciáljának vizsgálata az Európai Unióban. Ph.D értekezés, Kézirat.

Fatma, M. - Rahman, Z. - Khan, I. (2014): Multi-Item Stakeholder Based Scale to Measure CSR in the Banking Industry. International Strategic Management Review, 2(1): 9-20. https://doi.org/10.1016/j.ism.2014.06.001

Flavian, C. - Guinaliu, M. - Torres, E. (2005). The influence of corporate image on consumer trust: a comparative analysis in traditional versus internet banking. Internet Research, 15(4): 447-470. https://doi.org/10.1108/10662240510615191

Greening, D.W. - Turban, D.B. (2000): Corporate social performance as a competitive advantage in attracting a quality workforce. Business \& Society, 39(3): 254-280. https://doi.org/10.1177/000765030003900302 
Griffin, J. - Mahon, J. (1997): The corporate social performance and corporate financial performance debate. Twenty-five years of incomparable research. Business and Society, 36(1): 5-31. https://doi.org/10.1177/000765039703600102

Griffin, J. J. (2000): Corporate social performance: Research directions for the 21st century. Business and Society, 39(4): 479-491. https://doi.org/10.1177/000765030003900407

Härle, P. - Lüders, E. - Pepanides, T. - Pfetsch, S. - Poppensieker, T. - Stegemann, U. (2010): Basel III and European banking: Its impact, how banks might respond, and the challenges of implementation. McKinsey Working Papers on Risk, Number 26.

Islam, K.Z. (2012). Corporate Social Responsibility (CSR) and Issue to Corporate Financial Performance (CFP): An Empirical Evidence on Dhaka Stock Exchange (DSE) Listed Banking Companies in Bangladesh. European Journal of Business and Management, 4(11): 18-26.

Jo, H. - Kim, H. - Park, K. (2014). Corporate environmental responsibility and firm performance in the financial services sector. Journal of Business Ethics, 131(2): 1-28. https://doi.org/10.1007/s10551-014-2276-7

Joyner, B. E. - Payne, D. (2002): Evolution and implementation: A study of values, business ethics and corporate social responsibility. Journal of Business Ethics, 41(4): 297-311. https://doi.org/10.1023/A:1021237420663

Kotler, P. - Lee, N. (2004): Corporate social responsibility: Doing the most good for your company and your cause. John Wiley \& Sons.

Laidroo, L. - Sokolova, M. (2015): International banks' CSR disclosures after the 2008 crisis. Baltic Journal of Management, 10(3): 270-294. https://doi.org/10.1108/BJM-08-20140128

Lee, D.D. - Faff, R.W. - Langfield-Smith, K. (2009): Revisiting the vexing question: does superior corporate social performance lead to improved financial performance? Australian Journal of Management, 34(1): 21-49. https://doi.org/10.1177/031289620903400103

Lentner Csaba - Kolozsi Pál - Tóth Gergely (2010): A pénzügyi válságkezelés új útjai. EU Working Papers, 1/2010: 3-18.

Lentner Csaba - Szegedi Krisztina - Tatay Tibor (2015): Társadalmi felelősségvállalás a bankszektorban. Pénzügyi Szemle, 60(1): 96-104.

Lu, W. - Chau, K.W. - Wang, H. - Pan, W. (2014): A decade's debate on the nexus between corporate social and corporate financial performance: a critical review of empirical studies 2002-2011. Journal of Cleaner Production, 79(September): 195-206. https://doi.org/10.1016/j.jclepro.2014.04.072 
Malik, M. S. - Nadeem, M. (2014): Impact of corporate social responsibility on the financial performance of banks in Pakistan. International Letters of Social and Humanistic Sciences, 10(1): 9-19. https://doi.org/10.18052/www.scipress.com/ILSHS.21.9

Mallin, C. - Farag, H. - Ow-Yong, K. (2014): Corporate social responsibility and financial performance in Islamic banks. Journal of Economic Behavior \& Organization, 103(Supplement, July): S21-S38. https://doi.org/10.1016/j.jebo.2014.03.001

Marcia, M.C. - Otgontsetseg, E. - Hassan, T. (2013): Corporate Social Responsibility and its Impact on Financial Performance: Investigation of US Commercial Banks. Unpublished research paper, Department of Finance, Bentley University, Waltham, US.

Marom, I. Y. (2006): Toward a unified theory of the CSP-CFP link. Journal of Business Ethics, 67(2): 191-200. https://doi.org/10.1007/s10551-006-9023-7

McDonald, L.M. - Hung Lai, C. (2011): Impact of corporate social responsibility initiatives on Taiwanese banking customers. International Journal of Bank Marketing, 29(1): 50-63. https://doi.org/10.1108/02652321111101374

Mcllroy, D.H. (2008): Regulating risks: A measured response to the banking crisis. Journal of Banking Regulation, 9(4): 284-292. https://doi.org/10.1057/jbr.2008.15

Mohr, L.A. - Webb, D.J. - Harris, K. E. (2001): Do consumers expect companies to be socially responsible? The impact of corporate social responsibility on buying behavior. The Journal of Consumer Affairs, 35(1): 45-72. https://doi.org/10.1111/j.1745-6606.2001.tb00102.x

Mozghovyi, Y. - Ratnykova, I. (2011): Correlation between the Corporate Social Responsibility and Financial Performance of the Bank in Ukrainian Context. Corporate Ownership and Control, 8(2): 120-130. https://doi.org/10.22495/cocv8si2p6

Ofori, D.F. - Nyuur, R.B. - S-Darko, M.D. (2014): Corporate social responsibility and financial performance: fact or fiction? A look at Ghanaian banks: original research. Acta Commercii, 14(1): 1-11. https://doi.org/10.4102/ac.v14i1.180

Okwemba, E.M. - Mwalati, S. C. - Egessa, R. - Musiega, D. - Maniagi, G. M. (2014): Effect of Corporate Social Responsibility on Organisation Performance, Banking Industry Kenya, Kakamega County. International Journal of Business and Management Invention, 3 (4): 37-51.

Omoro, N. - Kinyua, H. - Okiro, K. (2014): Investment in Corporate Social Responsibility and Sustained Growth in Commercial Banks in Kenya, Journal of Emerging Issues in Economics. Finance and Banking, 3(2): 1047-1068.

Orlitzky, M. (2011): Institutional logics in the study of organizations: The social construction of the relationship between corporate social and financial performance. Business Ethics Quarterly, 21(03): 409-444. https://doi.org/10.5840/beq201121325 
Orlitzky, M. - Schmidt, F.L. - Rynes, S.L. (2003): Corporate social and financial performance: A meta-analysis. Organization Studies, 24(3): 403-441. https://doi.org/10.1177/0170840603024003910

Pérez, A. - Martinez, P. - del Bosque, R. (2013): The development of a stakeholder-based scale for measuring corporate social responsibility in the banking industry. Service Business, 7(3): 459-481. https://doi.org/10.1007/s11628-012-0171-9

Porter, M. - Kramer, M. (2011): The big idea - creating shared value - How to reinvent capitalism - and unleash a wave of innovation and growth. Harvard Business Review, 89(1-2): 62-77.

Rádóczy Klaudia (2017): Passziv és aktiv befektetési formák: Carhart-modell alkalmazhatósága öngondoskodás esetén. Várakozások és gazdasági interakciók. Szegedi Tudományegyetem, JATE Press, 141-156. o.

Rappaport, A. (2006): Ten ways to create shareholder value. Harvard Business Review, 84(9): 66-77.

Raihan, M.Z. - Bakar, R. - Islam, M.A. (2015): Impact of Corporate Social Responsibility (CSR) Expenditures on Financial Performance of Islami Bank Bangladesh Ltd. The Social Sciences, 10(2): 171-177.

Relano, F. - Paulet, E. (2012): Corporate responsibility in the banking sector: a proposed typology for the German case. International Journal of Law and Management, 54(5): 379-393. https://doi.org/10.1108/17542431211264269

Rogošić, A. (2014): Corporate social responsibility reporting of the banks in Bosnia and Herzegovina, Croatia and Montenegro. Theoretical and Applied Economics, 21(9): 71-82.

Ruf, B.M. - Muralidhar, K. - Brown, R M. - Janney, J.J. - Paul, K. (2001): An empirical investigation of the relationship between change in corporate social performance and financial performance: A stakeholder theory perspective. Journal of Business Ethics, 32(2): 143-156. https://doi.org/10.1023/A:1010786912118

Schaltegger, S. - Lüdeke-Freund, F. - Hansen, E.G. (2012): Business cases for sustainability: the role of business model innovation for corporate sustainability. International Journal of Innovation and Sustainable Development, 6(2): 95-119. https://doi.org/10.1504/ IJISD.2012.046944

Scholtens, B. (2008): Corporate Social Responsibility in the International Banking Industry. Business Ethics, 86(2): 159-175. https://doi.org/10.1007/s10551-008-9841-x

Schreck, (2011): Reviewing the Business Case for Corporate Social Responsibility: New Evidence and Analysis. Journal of Business Ethics, 103(2): 167-188. https://doi.org/10.1007/s10551-011-0867-0 
Sen, S. - Bhattacharya, C.B. (2001): Does doing good always lead to doing better? Consumer reactions to corporate social responsibility. Journal of marketing Research, 38(2): 225-243. https://doi.org/10.1509/jmkr.38.2.225.18838

Simpson, W. G. - Kohers, T. (2002): The Link Between Corporate Social and Financial Performance: Evidence from the Banking Industry. Journal of Business Ethics, 35(2): 97109. https://doi.org/10.1023/A:1013082525900

Soana, M. G. (2011): The Relationship Between Corporate Social Performance and Corporate Financial Performance in the Banking Sector. Journal of Business Ethics, 104(1): 133-148. https://doi.org/10.1007/s10551-011-0894-x

Tran, Y.T.H. (2014): CSR in Banking Sector: A Literature Review and New Research Directions. International Journal of Economics, Commerce and Management, II(11).

Truscott, R.A. - Bartlett, J.L. - Tywoniak, S.A. (2009): The reputation of the corporate social responsibility industry in Australia. Australasian Marketing Journal, 17(2): 84-91. https://doi.org/10.1016/j.ausmj.2009.05.001

Tschopp, D. (2012): Drivers of corporate social responsibility reporting; Case studies from three reporting companies. International Journal of Business and Social Research, 2(2): $1-11$.

Saxena, M. - Kohli, A.S. (2012): Impact of Corporate Social Responsibility on Corporate Sustainability: A Study of the Indian Banking Industry. The IUP Journal of Corporate Governance, 11(4): 39-54.

Vigano, F. - Nicolai, D. (2009): CSR in the European banking sector: evidence from a survey. In: Corporate Social Responsibility in Europe: Rhetoric and Realities. Edward Elgar Publishing.

Waddock, S.A. - Graves, S.B. (1997): The corporate social performance-financial performance link. Strategic Management Journal, 18(4): 303-319. https://doi.org/10.1002/(SICI)10970266(199704)18:4<303::AID-SMJ869>3.0.CO;2-G

Wu, M.W. - Shen, C.H. (2013): Corporate social responsibility in the banking industry: Motives and financial performance. Journal of Banking \& Finance, 37(9): 3529-3547. https://doi.org/10.1016/j.jbankfin.2013.04.023

Yeung, S. (2011): The role of banks in corporate social responsibility. Journal of Applied Economics and Business Research, 1(2): 103-115. 